\title{
Right-wing populism in New Turkey: Leading to all new grounds for troll science in gender theory
}

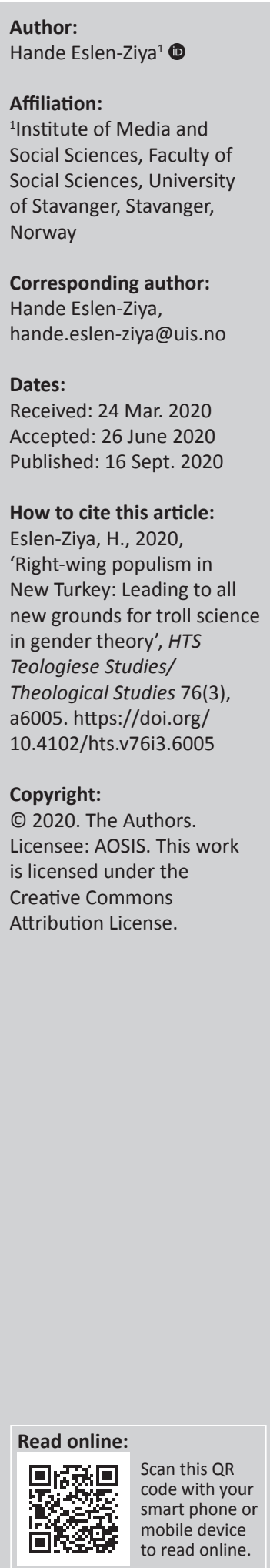

After years of progress in terms of gender and sexual rights, since 2012 Europe is facing a so-called gender backlash - opposition directed to issues related to reproductive policies and abortion, violence against women, lesbian, gay, bisexual, transgender, intersex, and queer (LGBTIQ) rights and gay marriages, gender mainstreaming and sex education at schools as well as antidiscrimination policies. In this article, firstly, by taking the anti-gender developments as point of reference, I examine the emergence of anti-gender movement in Europe via the use of what I call troll science. Troll science is based on (distorted) scientific arguments moulded into populist discourse, creating an alternative narrative on the conceptions of gender equality. Similar to troll accounts posting provocative, superfluous and even off-topic messages on social media to start arguments and quarrels aiming to distract, troll science, I argue, creates an alternative narrative opposing the scientific facts and discourses (i.e. climate change, evolution, vaccination and gender theory). Later, I discuss the emerging conservative troll-scientific discourses and the gendered public normative order of Adalet ve Kalkinma Partisi (AKP; Justice and Development Party) government, under the New Turkey. I previously argued that New Turkey and the society under the party's rule perpetuated by a new set of standards create an alternative narrative on the conceptions of gender equality through troll-science narratives. I concluded by showing how such ideological discourses help create emotional echo chambers enabling its fast distribution and acceptance by the ideologically conservative groups.

Contribution: This paper contributes to the Special Collection Gender Justice, Health and Human Development with the theory of troll-science it introduces to discuss the alternative and anti-gender scientific discourse that is dominating academia.

Keywords: Gender theory; Troll-science; Pseudo-science; Emotional echo chambers; AKP; Populism.

\section{Introduction}

Gender study is seen as a dangerous field in Latin America and Europe (Gimson 2019). Even after years of progress in terms of gender and sexual rights, since 2012 Europe is facing a so-called gender backlash - growing opposition to gender theory and the notion of gender equality (Grzebalska \& Soós 2016; Kuhar \& Zobec 2017). It is directed to issues related to reproductive policies and abortion, violence against women, LGBTIQ rights and gay marriages, gender mainstreaming and sex education at schools as well as antidiscrimination policies. According to Kuhar and Zobec (2017), this is a:

$[N]$ ew manifestation of resistance, shaped by new forms of organisation, new types of mobilisation and new discourses that seek to address wider audiences and not only traditional circles of conservative groups. (p. 31)

In this respect, this article is an attempt to study anti-gender mobilisation in Turkey pointing to both specificities unique to Turkey and links to the mobilisation against gender equality in Europe. I will argue that although Turkish anti-genderism has its similarities to the broader anti-gender trend, some aspects of this phenomenon are rather unique to Turkey and its socio-political context.

Firstly, by taking the anti-gender developments as point of reference, I will examine the emergence of anti-gender movement in Europe via the use of what I call troll science. Troll science is based on (distorted) scientific arguments (Kuhar 2015) moulded into populist discourse, creating an alternative narrative on the conceptions of gender equality. Similar to troll accounts posting provocative, superfluous and even off-topic messages on social media to start arguments and Note: Special Collection entitled Gender Justice, Health and Human Development, sub-edited by Cheryl Potgieter (DUT). 
quarrels aiming to distract, troll science, I argue, creates an alternative narrative opposing the scientific facts and discourses (i.e. climate change, vaccination and gender theory). Secondly, the article will discuss this newly emerging conservative troll-scientific discourses and the gendered public normative order of Adalet ve Kalkinma Partisi (AKP; Justice and Development Party) government, under the New Turkey (the governmental policies since 2014). I will argue that New Turkey and the 'social and political order under the party's rule maintained by a new set of norms and values' (Korkut \& Eslen-Ziya 2016:13) create an alternative narrative on the conceptions of gender equality and what it means to be woman and man by using such (distorted) scientific arguments which I will refer as troll-science narratives. I will further show that such narratives on gender are reinforced with the conservative religious doctrine. For this, I will study articles published in KADEM Kadın Araştırmaları Dergisi (Journal of Women's Studies [JWS]). KADEM JWS is the official, academic periodical of the Women and Democracy Association (KADEM). It is a peer-reviewed academic journal that publishes research on gender and women's studies. The assumption here is that under the New Turkey, an alternative anti-gender discourse within academia is being created. I will therefore argue that the anti-gender movement has an ambition to become an alternative field of knowledge production. Although this article focusses mostly on the Turkish case, the larger aim here is to display the key principles of anti-genderism as an ideology and strategy for a new discourse creation of relevance beyond the Turkish context.

\section{From gender-mainstreaming to anti-gender movement in Europe}

In this article, gender concept is taken as a process through which differences between sexes are built into structures, where they are consistently constructed and re-constructed in everyday practices (Lorber 1994; West \& Zimmerman 1987) as well as through population politics. Therefore, gender is something that is 'done' and performed as West and Zimmerman (1987) puts in their well-known work Doing Gender. It is through gender socialisation and gender role learning that both women and men learn what is expected of them, and such expectations in return form cultural knowhows of 'doing gender'. Gender is performed within certain institutional contexts, where the firm and binary division of gender are replaced with 'wide range and breadth of both biological sex and gender manifestations' (Butler 2004:42). Gender 'experiences produce different feelings, consciousness, relationships, skills - ways of being' (Lorber 1994:113). Gender research focussing on gender inequalities refutes the essentialist view attributing fixed and biological based differences between women and men and argues that such essentialist, anti-gender perspective leads to inequalities. My interest here lies in studying how socio-political arrangements (Connell 2002; Walby 1997) and right-wing populist discourses work to contribute to and maintain such inequalities, and what role the organised anti-gender, trollscientific discourses play to this extent.
Starting from 2012, throughout the Europe - and especially in Croatia, Italy, France, Hungary, Germany, Poland, Slovakia, Slovenia and Spain - anti-gender mobilisation gained a momentum and out-spoken resistance (Bracke \& Paternotte 2016; Grzebalska \& Soós 2016). The gender backlash that came from both inside and outside religious traditions started by rejecting gender as an analytical concept and it is mere definition: 'constitutive element of social relationships based on perceived differences between the sexes and a [...] a primary way of signifying relationships of power' (Scott 1986:1067). This brought questioning of gender mainstreaming both as an approach and policy tool (Council of Europe 1998):

$[T]$ he (re)organisation, improvement, development and evaluation of policy processes, so that a gender equality perspective is incorporated in all policies at all levels and at all stages, by the actors normally involved in policy-making. (p. 2)

The resistance towards the gender as an analytical concept and the development of anti-gender ideology and mobilisation meant backlash in gender mainstreaming and gender equality within the realm of politics, policy making, governance workforce and family life. This led to undermining the gender and its knowledge production 'and truth claims of many decades of gender studies scholarship' (Bracke \& Paternotte 2016:144). Such opposition according to Bracke and Paternotte (2016) and Kuhar (2015) projects for alternative and - I add - conservative knowledge production and new form of populist totalitarianism. The anti-gender mobilisation is more than a conservative backlash, but a new ideological discourse that combines both local but at the same time transnational European ties to set a new populist totalitarian agenda. Since 2012, it has managed to mobilise people at local grassroots level. For instance, in France, the $L a$ Manif Pour Tous (The Protest for Everyone) that filled the streets to protest same-sex marriages was one of the largest demonstrations in Europe. During the demonstration's slogans such as 'don't lay, a finger on our gender stereotypes', 'stop gender ideology', 'stop gender' or 'we want sex, not gender' illustrates how certain populist and anti-gender discourses were being constructed.

Korkut and Eslen-Ziya (2016:1) drawing data from over 5000 newspaper articles argue that 'the norms embedded in political discourse and circulated for public deliberation generate the discursive governance of population politics ... (where) politicians advance governance even without introducing major policy changes'. In the case of anti-gender mobilisation in Europe, the Catholic Church and Vatican does an agenda setting on anti-gender ideology. According to Bracke and Paternotte (2016):

[T] he movements that have gathered in the name of 'gender ideology' have been driven, to a large extent, by theological developments, as well as mobilisation efforts within the Roman Catholic Church. (p. 145)

The Catholic Church plays an important role in the anti-gender mobilisation. In the following section, I will show how the recent transformations in the gender enables 
contemporary anti-gender politics to be communicated, negotiated and discussed as a form of discursive governance where the troll-scientific arguments are formed into populist discourses.

\section{Science, gender and troll science}

As the gender theory and related discourses found its place within the academic world, the counter views also started emerging. Gender was seen as a strategic tool to erase up family all together, destroy femininity and masculinity or 'establish a gender order that goes beyond the binary gender system' (Kuhar \& Zobec 2017:34). This was evident in the protests that took place in Spain in 2005, Italy in 2007 and in Slovania in 2010 under the so-called 'family day', which later led its way into anti-gender movement. In all these protests, 'gender theory' was seen as the evil behind these progressive policies. Gender theory was presented as a battle between men and women (Graff \& Korolczuk 2017) and in the East European context as a neo-colonial project of the West (Korolczuk \& Graff 2018). It was in January 2015, when Pope Francis warned the believers against 'gender ideology' 'a dangerous imposition from wealthy Western countries on developing nations' (Korolczuk \& Graff 2018:797). Pope believed that having healthy and strong families is the only way to overcome this ideological colonisation ( $\mathrm{O}^{\prime}$ Connell 2015). The anti-colonial reference used by the far right was not at all about colonialism, but was a metaphor referring to the Western elite and their ideological dominance. Colonialism was separated from its actual history and used as a powerful discourse to implement anti-gender ideology (Korolczuk \& Graff 2018).

Trolls in social media are contentious, they target and they mock and most of the time, they act on behalf of the establishments (Bulut \& Yörük 2017), by impacting the language of politics. Similar to troll accounts posting provocative, superfluous and even off-topic messages on social media to start arguments and quarrels aiming to distract, troll science, I argue, aims to create an alternative narrative opposing the scientific facts and discourses. Although troll science is similar to Dawe's (2018:286) broadly defined concept, pseudoscience, 'a systematic form of knowledge- seeking activity that is being falsely presented as a science', it is different in its distribution speed. Similar to troll accounts' impact on spreading fake news, troll science is produced by rejecting scientific facts or acceptance of false facts and conspiracy theories (Szabados 2019:208) and is shared in circles to further disseminate such beliefs. Eslen-Ziya, McGarry and Jenzen et al. (2019) refer them as the emotional echo-chambers where common emotions are 'echoed' back and forth and shared by others. This, in return, not only helps beliefs disseminating into larger circles, but also allows such echoes to bring back emotions to its producer. In response, emotions get stronger as well as ideological. In this case then, troll-scientific arguments, by spreading fake information, are attached with emotions enabling them to be acceptable in certain circles - in this specific case ideologically conservative circles.
The use of troll science became evident, for instance, in Slovenia and Croatia where the Church and some of the non-governmental organisations (NGOs) (Kuhar 2015):

$[U]$ sed and abused scientific data in order to agitate for their goals: the non-recognition of gay marriage in Slovenia and the exclusion of non-heteronormative sex education modules from Croatian public schools. (p. 84)

In Poland, gender issues and gender mainstreaming were taken out of context and were presented as a threat to the Polish nation. The anti-gender arguments were given within an anti-colonialist, 'freedom fighting' framework (Petô 2015). The 'child in danger', 'moral confusion' and/or 'destroying foundations of society' (Grzebalska \& Petö 2018:166) were the discourses used. Another key theme of the populist discourse has been a form of bio-politics that views traditional family as the foundation of the society. In both Hungary and Poland, familialistic discourses have substituted women's reproductive rights and gender equality (Bowers du Toit et al. 2019). ${ }^{1}$

A new concept 'family mainstreaming' was introduced by the Hungarian government in 2010 to replace gender mainstreaming (Juhász 2012):

$[T]$ he ruling idea is that the two are in contrast, and gender mainstreaming creates 'single' people, and lobbies for homosexuals, thus worsening demography, whereas family mainstreaming works for heterosexual parents with children, and helps demography. (p. 4)

Similarly, in Poland, family mainstreaming aimed at 'bringing the family to the core of the political rules of the government' (Grzebalska \& Petô 2018:167). Clearly, the family mainstreaming aimed at demographic growth and was used to appropriate the critical gender studies discourse.

The anti-gender discourse in Europe clearly depicts a harsh backlash in gender issues framed by the religious fundamentalists and transnational right-wing illiberal populists. Family policies rooted in right-wing populistic Christian ideology, focussing on demographical growth, are all constructing a new illiberal universalism. Anti-genderism has become a political movement mobilising within (Korolczuk \& Graff 2018):

[E]xisting national and local groups, churches and political parties, and they are increasingly networking on the global level through international anti-choice coalitions, organisations such as the World Congress of Families and online petition platforms such as CitizenGo, which in December 2017 had over 8 million registered users worldwide. (p. 798)

This is performed via a shift from religious conservative (biblical) to conservative and fake-scientific discourse (troll science). Furthermore, the use of troll science and research instead of a biblical discourse and substituting it with the so-called rational but troll-scientific discourse 1.For further discussions about pro-natalism and institutional sexism, please see
Reconceiving Reproductive Health: Theological and Christian Ethical Reflections edited by Bowers du Toit et al. (2019). 
shape the gender discussions into what Kuhar (2015:84) calls a populist common-sense statement. The use of troll science in setting the populist agenda is also evident in debates over gender and gender equality within the Turkish context. In the following section, I will study the anti-gender mobilisation in Turkey pointing to both specificities unique to Turkey and links to the mobilisation against gender equality in Europe. I will show while Turkish anti-genderism has its similarities to the boarder anti-gender trend, some aspects of this phenomenon are rather unique to Turkey and its socio-political context.

\section{The Turkish context}

The beginning of new millennium for Turkey brought upon the concept of Europeanisation (Börzel 2002; Graziano \& Vink 2008; Olsen 2002) where the Turkish laws were adapted to the acquis communautaire ${ }^{2}$ (Eslen-Ziya 2007). During this process, women's civil society played a significant role promoting gender equality and gender equal legislation changes (Eslen-Ziya 2007, 2012, 2013; Içduygu 2011). But since 2007, the AKP government not only hesitated to further continue the European Union membership project (Patton 2007; Zihnioğlu 2013) but also gave its way to a gender backlash. Similar to the negative developments on gender equality within Europe, in Turkey too, anti-gender discourses were gaining momentum.

This 'new transition' is indicated by the AKP itself as the New Turkey. Under the New Turkey, AKP government adopted populist discourses involving Islamist elements of nationalism and conservatism. The previous research on AKP's gender politics shows party's policies and political discourses following pro-Islamic narratives that reproduce traditional gender roles (Cindoğlu \& Ünal 2017; Coşar \& Yeğenoğlu 2011; Unal 2015; Tür \& Çıtak 2008). Adalet ve Kalkinma Partisi's political agenda in return marginalised feminism, gender equality by presenting as an extreme ideology and desire for a world against Islam. In this article, I will show that such anti-feminist anti-gender political discourse functions along not only the intertwining of pro-Islamism, but also neo-liberalism, authoritarianism and conservatism.

As Korkut and Eslen-Ziya (2016:13) argues 'the social and political order under the party's rule maintained by a new set of norms and values' that operated as a counter-conduct, a counter-narrative (Cebeci 2016). Through these narratives, AKP's populism sets the rules for the majoritarian understanding of politics leading itself to stark polarisation of Turkish society. These narratives function as the discursive governance (Korkut \& Eslen-Ziya 2011, 2016, 2017) where the AKP government opposes gender equality among many other things. Discursive governance created by the AKP allows for public agenda setting through an active sense-making, a process in which the media and public discourse plays a critical disseminating and legitimating role, particularly in restrictive political settings (Burul \& Eslen-Ziya 2018).

Within the current decade, institutionalised Islam (Korkut \& Eslen-Ziya 2017) became a counter narrative of gender. This was happening along the same time with academic persecutions and self-censorships in critical gender studies. Hence, I argue that, differently than Europe, AKP government instead of attacking gender studies all together pursued for the creation of an alternative gender discourse, opening its way for a new discursive governance. The fact that science and research expenditures have not decreased in Turkey but doubled because Erdogan came into power exemplifies this well. According to Szabados (2019:220) as a percentage of gross domestic product, science and research expenditures have increased from $0.48 \%$ in 2003 to $0.88 \%$ in 2015 . However, such increase is used for supporting and disseminating the ideological discourse of AKP.

As Szabados (2019:220) argues, the attitude of the Erdoğan regime in Turkey towards science is more controversial and ideological. It is now Erdoğan who elects the members of the Turkish Academy of Science, which makes science academy a reflection of Turkish politics. It was in 2009 that the national science-funding agency banned an article on Darwin's birth ${ }^{3}$ and any publication of any books on evolution theory including the school textbooks. Moreover, in 2019, the Turkish Ministry of Education cancelled gender quality programmes at schools. ${ }^{4}$ Although all these strategies are exemplifying the anti-science turn of AKP government, I am interested studying what is happening parallelly through the development of troll-science discourses on gender theory. For this, I will focus on Women and Democracy Association's - KADEM - work. KADEM created by President Erdogan's daughter Sumeyye ErdoganBayraktar in 2013 has the 'aim to conserve the essential values of women in Turkey ${ }^{5}$ (read: guarding the so-called cultural essence - the family and gendered roles).

\section{KADEM (n.d.) mission statement:}

Conserving the essential values of women in Turkey ... and formulating common public awareness in societies in terms of women's rights and equal opportunities with the family and in social roles. (n.p.)

Through such an objective, KADEM clearly aligns itself with the governments' conservative position, situating women within the family (Akyüz \& Sayan-Cengiz 2016) and serves to institutionalise pro-government, right-wing populist gender ideology. For instance, by representing the government as the women's representative organisation, KADEM writes Shadow Reports for The Convention on the Elimination of all Forms of Discrimination Against Women (CEDAW). In 2015, it also worked with the government on Istanbul Convention. In all these, KADEM actively supports policies through 3.See https://www.nature.com/news/2009/090310/full/news.2009.150.html. 4.See https://ahvalnews.com/gender-equality/turkeys-educational-authorities-cancelgender-equality-programmes.

5.See https://kadem.org.tr/kadem-hakkinda/. 
protecting family as an institution and embracing gendered roles (women as mothers and wives and men as bread winners and head of the households) where patriarchal order is protected.

KADEM also plays a significant role in creating troll-scientific discourses for public agenda setting ${ }^{6}$ on issues related to gender equality and women's rights in Turkey. In the next section, by studying the academic articles published by KADEM at JWS, I will illustrate troll-science discourses on gender under public normative order of AKP government.

\section{Trolling science, creating new gender discourses}

According to Rigney (1991), anti-intellectualism has three scopes: religious anti-rationalism, populist anti-elitism and unreflective instrumentalism. Although in Turkey, we see almost all three dimensions of anti-intellectualism (i.e. removal of Darwin's theory of evolution from school curriculum and/or the inclusion of jihad as a patriotic spirit in Imam-Hatip schools' curriculum ${ }^{7}$ ), I argue that the anti-gender discourse is being created via what appears as a religious-rational scientific discourse. In other words, the anti-gender and populist narratives of AKP government are supported by newly emerging academic, troll-scientific arguments and theories - and unlike in Europe - via the use of Islamic rhetoric. KADEM and its academic journal the JWS play a major role in both support and development of such populist common-sense statements. The JWS is a peer-reviewed academic journal that publishes research on gender and women's studies biannually. Albayraktar (2015) wrote, in the notes from the editor, that one of the main goals of the journal is to bring new perspectives to women's issues.

Journal of Women's Studies, instead of taking singular approaches to women's issues, it aims to open up such discussions to a wider academic audience and intellectuals in the light of new and different perspectives. In addition, it aims to present criticisms and develop new concepts, especially considering the hegemonic discourses and analyses in women's studies in our country, taking into account the alternative orientations and conceptualisations of the international academy in women's studies (Albayraktar 2015:8).

In this section by looking at the so-called scientific arguments created, I will outline the emerging conceptualisations on gender and women's issues. I will do this by linking the troll-scientific developments to the increasing right-wing populism both nationally (in Turkey) and transnationally (rest of Europe).

Since its establishment, KADEM has been organising academic conferences, seminars and communes on various topics ranging from the role of family in children's religious education to women within the Islamic family law. KADEM (n.d.), according to its vice-chair:

$[B]$ ases itself on the wisdom of its own land, principles of its own faith ... and questions imposed understanding and serves as a protective shield against those who bale the values of our society of the injustices women suffer. ${ }^{8}$ (n.p.)

Although there is not a straightforward attack on gender studies or gender equality as there is in Hungary, for instance, the AKP government and KADEM reflect their anti-gender discourses through two dynamics: (1) via the protection of the so-called values of society,' serving as a shield against those who say it is the society that create injustices for women for instance' (KADEM mission statement) and (2) by reproducing an essentialist gender ideology. Although the first one disables them to do things to change the patriarchal dynamics of the culture, the other one marginalises the efforts of feminists and feminist organisations, making it impossible to work together.

Since 2015, the JWS has published eight issues. Each issue starts with a note from the editor and an interview and includes about five articles on women's issues from different disciplines such as law, political science, economy, art, anthropology and so on, solidifying their own perception of gender equality and women's rights with scientific knowledge. The content analysis of the articles showed seven recurrent themes: the concept of gender equality versus gender justice; the role of family; women in the workforce and the glass-ceiling syndrome; the women's political representation; migration; poverty; and violence. In the following sections, I will focus on the first two of these themes: gender equality versus justice and the role of the family.

\section{Gender equality versus gender justice}

It was in 2010 that Erdogan introduced the gender equality into discussion. At a meeting with women's organisations, he declared that women are not equal to men and that he does not believe in equality between them. 'Women can only be equal to women' ${ }^{9}$ he uttered. He also claimed that the biological differences meant women and men could not serve the same functions, and that some work was not suitable for women because of their 'delicate nature'.

Women and men could not be treated equally because it goes against the laws of nature ... Their characters, habits and physiques are different ... You cannot place a mother breastfeeding her baby on an equal footing with men ... You cannot make women work in the same jobs as men do, as in communist regimes ... You cannot give them a shovel and tell them to do their work. This is against their delicate nature (Guardian 2014).

8.See https://kadem.org.tr/kadem-hakkinda/.

9.See https://www.theguardian.com/world/2014/nov/24/turkeys-president-receptayyiperdogan-women-not-equal-men. 
He also gave a similar speech at summit in Istanbul stating: 'Our religion [Islam] has defined a position for women: motherhood'. Erdogan later criticised how feminists in Turkey reject the idea of motherhood. Erdogan's rejection of feminist discourses is later supported by Yilmaz's (2015) academic work in JWS, where she argues that feminist literature belongs to the West and cannot be embraced by the Turkish culture. Such distancing from feminist discourses is also evident in the West where the Vatican's Pontifical Council for the Family asserted that a (Corredor 2019):

$[F]$ eminist ideology ... known as 'gender' has led to a misunderstanding of the complementary difference between men and women and a growing confusion about sexual identity that complicates the assumption of roles and sharing of tasks in the home. (p. 615)

Later Vatican published articles that clarify the Holy See's stance on issues in a Lexicon: Ambiguous and Debatable Terms regarding Family Life and Ethical Questions (2006). It is a compendium explaining the importance of family and life. Its editors' summary is presented below (George Cardinal Pell, Archbishop of Sydney):

This long-awaited English translation of the Lexicon will be an invaluable resource to all those who genuinely seek to understand the profound truth, goodness and beauty of marriage and family. It is a gift to the faithful and to the broader community from the Church. In response, each of us is called to reflect on how we can best use it to proclaim the authenticity of Christ's message, especially in the areas of marriage and family in the third millennium. It will greatly assist all those of good will who seriously wish to learn the truth about marriage and family and to embark on the New Evangelisation. (n.p.) $)^{10}$

In one of its chapter, Bishop Óscar Alzamora Revoredo (2003) stresses that:

$[D]$ ifferences between men and women, beyond the obvious and not anatomical ones, do not correspond to a fixed nature, but are products of the culture of a certain country or epoch. (p. 465)

In other words, he argues that gender theory unsettles the so-called moral fabric of society as it encourages people to "'invent" him/herself' (Alzamora Revoredo 2003:465), and by erasing the so-called natural differences between women and men. This, they argue, will in return promote homosexuality and result in gender confusion.

A similar troll-scientific discourse denying gender theory and feminist theory is published at JWS. Similar to both Erdogan's and Vatican's populist anti-gender, anti-feminism discourses, it talks about how women and men cannot be equal, as it is against nature. Yilmaz (2015), for instance, similar to the right-wing rhetoric of the West, opposes the gender concept that defines gender roles as socially constructed rather than a biologically predetermined. Gender then becomes a rhetorical device used by either the AKP government or Vatican to 'counter gender and sexual equality policy' (Corredor 2019:616) and to advance political goals.

10.See https://www.amazon.com/Lexicon-Ambiguous-Debatable-Regarding-Questions/ $\mathrm{dp} / 1559220503$
In her article 'Participation of Women in Politics in Turkey within the Perspective of Gender Equality and Justice', Yilmaz develops the gender justice rhetoric as a response to feminist scholars as well as women's movement.

Why men and women acquire different roles and statuses in social life have been among the topics that are constantly discussed up to this date. The concept of equality created in this context emphasises that there should be no difference between these two genders and emphasises that women and men should be treated equally without being subjected to any distinction in both social and private life. But the concept of equality cannot explain the current situation on this issue as necessary and ignores the fact that women and men are different by creation. However, the attitude of men and women to life and their expectations and powers are also different.

Yilmaz in another article titled 'A New Momentum: Gender Justice in the Women's Movement' published at Turkish Policy Quarterly further emphasises her opposition to feminist scholars in Turkey arguing that they have 'created a homogenous image of women, thus ignoring the differences among them' (Yilmaz 2015:108). She claims that 'in the quest for equality, the endeavour was to make women exist through masculinisation, and thus women were detached from the female identity' (Yilmaz 2015:108). According to Yilmaz, introducing the notion of gender justice or gender equity and abandoning the concept of gender equality will help develop an understanding of the differences both among women and between women and men. Otherwise, she argues, the universalistic, Western feminist demands on gender quality and women's rights will bring more harm than good. Her anti-genderism is a reflection of the Islamic interpretation of women and men where they are seen as different by nature (fitrat). Although Islam sees that women and men different by nature, at the same time it finds them complementary to one another: where women and men take different social roles and duties. In return, gender justice becomes a concept highlighting the gendered-based division of labour where duties are naturally assigned to women and men, leading to family mainstreaming.

\section{Family mainstreaming}

Before 08th of March 2019, The Turkish Family Assembly through social media distributed their motto; Stop the global war on the family, the terrorism of gender equality and homosexuality is a crime against humanity, the exact slogans that were used in Italy, France and Hungary. One of their demands was the annulment of the Istanbul Convention and the repeal of Act. No. 6284 that aims to end violence against women as well as the restoration of men as the head of the family. The antigender campaigning in Turkey, similar to the one led by the Catholic Church in Poland (Grzebalska \& Petö 2018:169) and in Vatican (Corredor 2019), evolved around three major issues: protection of family, Istanbul convention and the role of men within the family. Gender was seen as a threat to family, and to the Turkish society in general. 
Korkut and Eslen-Ziya's (2018) analyses of Friday hutbes (sermons) collected in 10 cities over a period of 23 weeks show a pro-family narrative with distinctive roles and duties attributed to both women and men. They argue that the emphasis on family in hutbes is, in fact, an attempt to lessen the change Turkey is going through with modernisation and to preserve the historically traditional and patriarchal structure of families. In an early study, Korkut and EslenZiya (2016) trace the political discourse in relation to population politics and conclude that the three children slogan uttered by Erdogan constructs a certain female subjectivity.

'For a young population, citizens should always have three children [...], scientifically even two children suggest decline' (NTV 2009). ${ }^{11}$

In the religious hutbes, women are defined within familial roles - primary responsibility to give birth and be alongside men, whereas men enjoy control over their women relatives' - daughters, sisters, wives and mothers - body and sexuality. The findings of Korkut and Eslen-Ziya's (2018), showing hutbes having distinctive family narratives around gender roles and reproduction and even sexualities, are also evident within the troll-scientific narratives. For instance, the below quotation from Tekin (2017) clearly feeds into the Turkish populist political discourse under the New Turkey:

\begin{abstract}
As a matter of fact, family, women, sex, intimacy ... etc. many concepts, categories and structures today are the subject of multidimensional debate and destruction. Finally, the age of marriage is delayed, family building is not encouraged, divorce (rates) are increasing, privacy is weakening; society is becoming an anomie. In the history of mankind, the family is heterosexual but now legal status of homosexual marriages and even adoption of children is desired by these families thus family is being subjected to deconstruction and it is one of the important discussion topics in today's world ... The results obtained with the deconstruction show those weaknesses: First, human is living in the universe, which is given to him and the qualities of the male and female categories are more natural in terms of building a family. The opposite is to force the human nature to its nature's opposite... (p. 14)
\end{abstract}

As the above extract indicates, family is defined as a sacred unit where women have reproductive responsibilities, and the opposite will mean a challenge to human nature. Just like in Europe, we see the replacement of gender mainstreaming concept with that of family mainstreaming. Although gender mainstreaming is about evaluating the different implications for people of different genders at all policy and legislative levels, family mainstreaming is just the opposite, and it creates single typology of women - mothers and wives. Family mainstreaming represents only heterosexual people and heterosexual families with the goal to promote population growth. By bringing the family - but not the single individual to the core of the demographic growth - it is used to appropriate the critical gender studies discourse.

11.NTV, 2009, Erdoğan: Iş işten geçmeden en az 3 çocuk [Erdoğan: Before it is too late at least 3 Children]. Available online at http://www.ntv.com.tr/turkiye/erdogan-isisten-gecmeden-en-az-3-cocuk,ZEQhCeWHVkSO6IEDhd72Ng, accessed 07 June 2019.
The differential and essentialist roles assigned to women and men, according Yilmaz (2015:110), cannot be the cause for a hierarchy:

The fact that the duty to administer the family has been laid upon men does not generate a hierarchical order in any case and does not prevent the equality between women and men as human beings and subjects of God.

Gender justice on the contrary, she argues, 'will provide fair and proper sharing of roles in favour of women' (Yilmaz 2015:112). However, defining women as mothers and giving them a primary responsibility of childbearing and rearing not only assigns them the responsibility for raising the 'future of Turkey' (Korkut \& Eslen-Ziya 2018:63), but also allocates state responsibility for social protection to families. This is as Kandiyoti (2016) puts a mere reflection of neoliberal transformation of employment and welfare regimes. The neo-liberal and right-wing populist discourses of New Turkey have been cultivating the public narrative through discursive governance and religious sermons and new trollscientific arguments. Through these academic conferences, seminars and publications, the discursive governance is implemented, turning anti-gender movement into an alternative field of knowledge production. Hence, as I show as it is in the case of Europe, in Turkey too, troll science is being used to providing scientific material to support or justify gender inequalities (Kuhar 2015) and institutionalising pro-government, conservative and patriarchal discourses.

\section{Concluding: Anti-genderism as an alternative field of knowledge production}

One of the important aims of the anti-gender movement is creating an alternative troll-scientific knowledge to support the existing right-wing populist and conservative ideology of the governments in power. In Europe, this is performed through attacks on gender research and gender studies programmes within universities. Central European University in Hungary is a desolate example for that where Hungarian Prime Minister Viktor Orban banned gender studies programme. ${ }^{12}$ Gender studies and gender theory - as it is in the case in Turkey in Europe too - is criticised for being non-academic and ideological (Kuhar \& Zobec 2017), and the anti-gender movement has the goal to become the alternative science in this field. To this end, the content of the anti-gender academic conferences and seminars and articles published all serve this purpose, becoming the alternative field of knowledge production. According to Ayhan (2019), antigenderism in Turkey has manifested itself through recent political economic transformation:

Indeed, the Turkish welfare regime has been undergoing important transformations since 2002 with changes in social security and health care, flexibility in the labour market and privatizations (2008). The new social security law opposed

12.See https://www.independent.co.uk/news/world/europe/hungary-bans-genderstudies-programmes-viktor-orban-central-european-university-budapesta8599796.html. 
fiercely by labour organizations, decreased government contribution in wages, pensions and health care and increased minimum age for retirement. Flexible/part time employment of civil servants was introduced through these new regulations. Privatization of state-owned enterprises, a phenomenon dating back to 1980s in Turkey, was accelerated under AKP governance, leaving thousands unemployed as a result. (p. 3)

As the state transforms away from the welfare regimes, family as well as women within the family become the natural care provider. Hence, anti-genderism within academia helps support the public narratives, 'deliberately setting conservative discourses geared to sustain public narratives in line with traditional gender roles and identities' (Korkut \& Eslen-Ziya 2018:63).

The academic articles analysed so far, while questioning gender theory, advocates for women's work within the family and mirror the neo-liberal policies of New Turkey so that they can continue with their home-caring responsibilities. Hence, with the significant gender backlash, the New Turkey is observed with an agenda setting at an academic level, trolling science with reference to Islam and Islamic discourses. Such ideological discourses then create emotional echo-chambers (Eslen-Ziya et al. 2019) - enabling its fast distribution and acceptance by the ideologically conservative groups. In other words, the troll-scientific arguments that spread fake information are connotated with religious arguments and ideologies become emotionally loaded and get easily accepted in ideologically conservative circles. It becomes so intertwined that rejection of troll science becomes rejection of the Islamic doctrine, and hence, no one dares to question the former without being accused of questioning the latter. In return, AKP government is not only hesitating to further with EU-membership project (Kardas 2008; Patton 2007; Zihnioğlu 2013) but as of 2011 is taking a completely new turn with anti-gender discourses. In this article, I showed how via the introduction of troll science to support anti-gender and conservative discourses within academia, AKP government is furthering its neoliberal-conservative regulation on three main policy areas: reproduction, sexuality and family.

The contribution of the article lies in the fact that it names anti-genderism as a separate field of knowledge production. To illustrate this, I focussed on the use of scientific knowledge to produce anti-gender discourses. I tackled down these distorted scientific arguments moulded into populist discourses and outlined what these new troll perspectives are, and what alternative orientations and conceptualisations regarding gender and women's issues are emerging. I then lined these developments and discourse setting on gender issues to gender equality and women's rights discourses both nationally (in Turkey) and transnationally (rest of Europe). Through the combination of religious discourses within scientific articles, they are explicitly arguing that preservation of the 'natural' union between men and women is essential both for the wellbeing of the children as well as for the development of 'healthy' societies. The use of gender and gender theory as a rhetorical device by the right-wing populists for political purposes and to advance political goals counter gender and sexual equality policies, creating a gender backlash at all levels of society. Via this new and alternative, the so-called scientific discourse 'regenerates the issues of family and marriage as an ideological battleground of contemporary cultural wars' (Kuhar 2015:90), where there is an ever-increasing intolerance to critical thinking. As Gençoğlu (2019) puts, this has:

$[R]$ adically changed the meaning of being an academic in Turkey as it has changed the relations among academic and the university administration, and between academics and students. Many academics are under strict surveillance not only by the government but also university administration or students. (p. 9)

Under such anti-intellectualism and troll science, hegemonic discourses become the conservative narratives characterised by anti-genderism and patriarchal populist right-wing discourses. It devalues intellectual activity and critical thinking.

\section{Acknowledgements}

I would like to thank the anonymous reviewers whose comments and suggestions led to a significant sharpening of this article. I am indebted to the 'kvinner til topps' programme and the 'shut up and write!' sessions at the University of Stavanger, which enabled me to work on this article without interruption.

\section{Competing interests}

The author declares that she has no financial or personal relationships that may have inappropriately influenced her in writing this research article.

\section{Author's contributions}

H.E-Z. is the sole author of this research article.

\section{Ethical considerations}

This article followed all ethical standards for research without direct contact with human or animal subjects.

\section{Funding information}

This research received no specific grant from any funding agency in the public, commercial or not-for-profit sectors.

\section{Data availability statement}

Date sharing is not applicable to this article as no new data were created or analysed in the study.

\section{Disclaimer}

The views and opinions expressed in this article are those of the author and do not necessarily reflect the official policy or position of any affiliated agency of the author. 


\section{References}

Akyüz, S. \& Sayan-Cengiz, F., 2016, “'Overcome your anger if you are a man”: Silencing women's agency to voice violence against women', Women's Studies International Forum 57, 1-10. https://doi.org/10.1016/j.wsif.2016.03.004

Albayraktar, S., 2015, 'From the editor', Journal of Women's Studies 1(2), 8.

Ayhan, T., 2019, KADEM's 'gender justice' or the momentum of anti-genderism in Turkey, viewed 07 November 2019, from https://blogs.Ise.ac.uk/gender/2019/ 04/29/kadems-gender-justice-in-turkey/.

Börzel, T., 2002, 'Member state responses to Europeanization', Journal of Common Market Studies 40(2), 193-214.

Bowers du Toit, N., Chilongozi, M.N., Davids, H.R., Kotzé, G.R., Kotzé, M., Marais, N. et al., 2019, Reconceiving reproductive health: Theological and Christian ethical reflections, AOSIS, Cape Town.

Bracke, S. \& Paternotte, D., 2016, 'Unpacking the sin of gender', Religion and Gender 6(2), 143-154. https://doi.org/10.18352/rg.10167

Bulut, E. \& Yörük, E., 2017, 'Mediatized populisms| digital populism: Trolls and political polarization of Twitter in Turkey', International Journal of Communication 11, 25.

Burul, Y. \& Eslen-Ziya, H., 2018, 'Understanding "New Turkey" through women's eyes: Gender politics in Turkish daytime talk shows', Middle East Critique 27(2), 179-192.

Butler, J., 2004, Undoing gender, Routledge, New York, NY.

Cebeci, M., 2016, 'De-Europeanisation or counter-conduct? Turkey's democratisation and the EU', South European Society and Politics 21(1), 119-132.

Cindoğlu, D. \& Ünal, D., 2017, 'Gender and sexuality in the authoritarian discursive strategies of "New Turkey"', European Journal of Women's Studies 24(1), 39-54. https://doi.org/10.1177/1350506816679003

Connell, R.W., 2002, Gender, Polity, Cambridge.

Corredor, E.S., 2019, 'Unpacking "gender ideology" and the global right's antigende countermovement', Signs: Journal of Women in Culture and Society 44(3), 613-638. https://doi.org/10.1086/701171

Coşar, S. \& Yeğenoğlu, M., 2011, 'New grounds for patriarchy in Turkey? Gender policy in the age of AKP', South European Society and Politics 16(4), 555-573. https:// doi.org/10.1080/13608746.2011.571919

Council of Europe, 1998, Gender mainstreaming, conceptual framework, methodology and presentation of good practices, Final report of activities of the group of specialists on mainstreaming (EG-S-MS), Council of Europe, Strasbourg.

Dawes, G.W., 2018, 'Identifying pseudoscience: A social process criterion', Journal for General Philosophy of Science 49(3), 283-298. https://doi.org/10.1007/s10838017-9388-6

Eslen-Ziya, H., 2013, 'Social media and Turkish feminism: New resources for social activism', Feminist Media Studies 13(5), 860-870. https://doi.org/10.1080/14680 777.2013.838369

Gençoğlu, F., 2019, 'On the construction of identities: An autoethnography from Turkey', International Political Science Review 36(3), 779-798. https://doi. org/10.1177/0192512119858369

Gimson, S., 2019, In the attack on experts, gender studies is often the first target viewed 01 November 2019, from https://www.timeshighereducation.com/blog/ attack-experts-gender-studies-often-first-target.

Graff, A. \& Korolczuk, E., 2017, 'Worse than communism and Nazism put together: War on gender in Poland', in W.R. Kuhar \& D. Paternotte (eds.), Anti-gender campaigns in Europe: Mobilizing against equality, pp. 175-194, Rowman \& Littlefield International, London \& New York, NY.

Graziano, P. \& Vink, M., 2008, Europeanization, Palgrave Macmillan, Basingstoke.

Grzebalska, W. \& Petö, A., 2018, 'The gendered modus operandi of the illiberal transformation in Hungary and Poland', Women's Studies International Forum 68 164-172. https://doi.org/10.1016/j.wsif.2017.12.001

Grzebalska, W. \& Soós, E.P., 2016, Conservatives vs. the 'culture of death'. How progressives handled the war on 'gender', viewed 01 November 2019, from https://www.feps-europe.eu/resources/publications/364-conservatives-vs-theculture-of-death-how-progressives-handled-the-war-on-gender. html.

Içduygu, A., 2011, 'Interacting Actors: The EU and civil society in Turkey', South European Society and Politics 16(3), 381-394. https://doi.org/10.1080/13608746. 2011.598351

Juhász, B., 2012, Orbán's politics: A gender perspective, Friedrich Ebert Foundation, Budapest.
Kandiyoti, D., 2016, 'Locating the politics of gender: Patriarchy, neo-liberal governance and violence in Turkey', Research and Policy on Turkey 1(2), 103-118. https://doi. and violence in Turkey', Research and Poli
$\mathrm{org} / 10.1080 / 23760818.2016 .1201242$

Kardas, Ş., 2008, 'Turkey under the justice and development party: Between transformation of "Islamism" and democratic consolidation? Critique,' Critical Middle Eastern Studies 17(2), 175-187.

Korkut, U. \& Eslen-Ziya, H., 2011, 'The impact of social conservatism on population politics in Poland and Turkey', Social Politics: International Studies in Gender, State \& Society 18(3), 387-418. https://doi.org/10.1093/sp/jxr014

Korkut, U. \& Eslen-Ziya, H., 2016, 'The evolution of the pro-birth regime in Turkey: Discursive governance of population politics', Social Politics: International Studies in Gender, State and Society 23(4), 555-575. https://doi.org/10.1093/sp/jxw003

Korkut, U. \& Eslen-Ziya, H., 2017, Politics and gender identity in Turkey: Centralised Islam for socio-economic control, Routledge Studies in Middle Eastern Politics, London and New York, NY.

Korkut, U. \& Eslen-Ziya, H., 2018, Politics and gender identity in Turkey: Centralised Islam for socio-economic control, Routledge Studies in Middle Eastern politics, London.

Korolczuk, E. \& Graff, A., 2018, 'Gender as "Ebola from Brussels": The anticolonial frame and the rise of illiberal populism', Signs: Journal of Women in Culture and Society 43(4), 797-821. https://doi.org/10.1086/696691

Kuhar, R., 2015, 'Playing with science: Sexual citizenship and the Roman Catholic Church counter-narratives in Slovenia and Croatia', Women's Studies International Forum 49, 84-92. https://doi.org/10.1016/j.wsif.2014.07.005

Kuhar, R. \& Zobec, A., 2017, 'The anti-gender movement in Europe and the educational process in public schools', CEPS Journal 7(2), 29-46.

Lorber, Judith, 1994, 'Night to his day: The social construction of gender', in Paradoxes of Gender, pp. 13-15, Yale University Press.

NTV, 2009, Erdoğan: Iş̧ işten geçmeden en az 3 çocuk [Erdoğan: Before it is too late at least 3 Children], viewed 07 June 2019, from https://www.ntv.com.tr/turkiye/ erdogan-is-isten-gecmeden-en-az-3-cocuk,ZEQhCeWHVkS06IEDhd72Ng.

O'Connell, G., 2015, 'Full transcript of Pope's press conference on flight from Manila', America Magazine, viewed 13 July 2020, from https://www.americamagazine. $\mathrm{org} /$ content/dispatches/full-transcript-popes-press-conference-flight-manila.

Olsen, J., 2002, 'The many faces of Europeanization', Journal of Common Market Studies 40(5), 921-952.

Pető, A., 2015, "'Anti-gender" mobilisational discourse of conservative and far right parties as a challenge for progressive politics', in E. Kováts, \& M. Põim (eds.), Gender as symbolic glue. The position and role of conservative and far right parties in the anti-gender mobilizations in Europe, pp. 62-82, Foundation for European Progressive Studies and Friedrich-Ebert-Stiftung, Brussels and Budapest.

Revoredo, A., 2003, 'An ideology of gender: Dangers and scope', Pontifical Council for the Family, pp. 465-482, Routledge, New York, NY.

Rigney, D., 1991, 'Three kinds of anti-intellectualism: Rethinking Hofstadter', Sociological Inquiry 61(4), 434-451. https://doi.org/10.1111/j.1475-682X.1991. tb00172.x

Scott, J.W., 1986, 'Gender: A useful category of historical analysis', American Historical Review 91(5), 1053-1075. https://doi.org/10.2307/1864376

Szabados, K., 2019, 'Can we win the war on science? Understanding the link between political populism and anti-science politics', Populism 2(2), 207-236.

Tekin, M., 2017, 'Gender and justice from the deconstruction to reconstruction', in International social gender justice Congress: Women and family, p. 114, KADEM, Istanbul.

The Guardian, 2014, Recep Tayyip Erdoğan: 'women not equal to men', viewed 13 June 2020, from https://www.theguardian.com/world/2014/nov/24/turkeyspresident-recep-tayyip-erdogan-women-not-equal-men.

Tür, Ö. \& Çıtak, Z., 2008, 'AKP ve Kadin: Teskilatlanma, Muhafazakarlik ve Turban', Mulkiye Dergi 252, 259-274.

Unal, D., 2015, 'Vulnerable identities: Pious women columnists' narratives on Islamic feminism and feminist self-identification in contemporary Turkey', in Women's studies international forum, vol. 53, pp. 12-21, Elsevier Ltd., Pergamon.

Walby, S., 1997, Gender transformations, Routledge, Londra.

West, C. \& Zimmerman, D.H., 1987, 'Doing gender', Gender \& Society 1(2), 125-151.

Yılmaz, S.A., 2015, 'A new momentum: Gender justice in the women's movement', Turkish Policy Quarterly 13(4), 107-115.

Zihnioğlu, Ö., 2013, 'The "civil society policy" of the European Union for promoting democracy in Turkey: Golden goose or dead duck?', Southeast European and Black Sea Studies 13(3), 381-400. 